\title{
Analysis of Criminal Liability as Doer of Preening Criminal (Case Study in the Blora State Court)
}

\author{
Haris Wahyu Sunarno ${ }^{1}$ and Akhmad Khisni ${ }^{2}$
}

Abstract: Criminal beatings lately occur a lot because of actions from one person to another outside the normal limits. Crimes that often occur are beatings regulated in the criminal law book, namely Article 170 of the Criminal Code. The formulation of the problem in this study is how is the form of criminal responsibility towards the perpetrators of the beating crime committed by more than one perpetrator, and what are the obstacles in the criminal justice process against the perpetrators of the beatings and their solutions. The method used in the form of sociological juridical research specifications descriptive analysis. Data consists of primary data and secondary data taken by the method of document collection, interviews, and literature study. Based on the research it was concluded (1) The form of a system of criminal justice process in the flow of the trial in the decision Number 94 / Pid.B / 2019 / PN Bla as a form of criminal responsibility towards the perpetrators of beating crimes that are processed in the criminal justice process, (2) Obstacles deep inhibition in the criminal justice process against the perpetrators of the beating crime including the investigation process in presenting witnesses, the prosecution process that takes time, and article 170 of the Criminal Code which still has ambiguous in theoretical.

Keywords: Criminal Liability, Beating Criminal Acts

\section{Introduction}

Indonesia is a state of law, the statement contained in the Elucidation of the 1945 Constitution of the Republic of Indonesia states that "The State of Indonesia is based on law (rechtstaat) not based on mere power (machtstaat)", as a rule of law then Indonesia has a series of regulations or law so that people's interests can be protected. The $4^{\text {th }}$ paragraph of the Preamble of the 1945 Constitution of the Republic of Indonesia which is the constitutional basis of the country states that one of the objectives of the state is to create public welfare. So all efforts and development carried out by this country must lead to this goal so as to create people's welfare.

The lack of legal awareness in today's society causes distrust between members of the community itself as well as distrust with law enforcement officials and the government. Especially with the difficult economic conditions of our country today, resulting in the emergence of crime that occurs in a background of society because of the increasing necessities of life in each member of the community. Conditions that occur every day and are experienced by the community such as mugging, mugging, theft, robbery, torture, rape, murder, teenage brawl, or better known as "street crime" or "under crime" is a challenge for the law enforcement process.

The development of crime as described above, the law occupies an important position to overcome the problem of this crime. Legal instruments are needed to resolve conflicts or crimes that exist in society. One of the efforts to prevent and control crime is to use criminal

\footnotetext{
1 Student of Master of Law, Sultan Agung Islamic University (UNISSULA), Semarang, email: hariswahyu86@gmail.com

${ }^{2}$ Lecturer of Faculty of Law, Sultan Agung Islamic University (UNISSULA), Semarang
} 
law with sanctions in the form of crime. ${ }^{3}$

In Indonesia the law is seen as the legal commander of the perpetrators of criminal acts. One of the acts of speech was the beating. Criminal beatings lately occur a lot because of actions from one person to another outside the normal limits. The criminal act that often occurs is the beatings regulated in the criminal law book, Article 170 KUHP. Usually a mob act is carried out by more than one person and has been planned to use tools such as beams, wood or other sharp weapons. ${ }^{4}$

Violence committed by someone both together and alone against people or goods is increasing and is disturbing the public and law enforcement officers. Book of Criminal Law Book II Chapter V regulates crimes against public order contained in Articles 153-181. In Article 170 Paragraph (1) of the Criminal Code, it is stated that: "Anyone who publicly acts together violates a person or property ..." can be seen in the article that has elements that provide a limit to being able to ensnare someone who committing a violent crime. ${ }^{5}$

As has been quoted in the Criminal Law Act that as for the perpetrators of criminal acts that are proven against the law, imprisonment for imprisonment for deprivation of the deeds he has done. In the case of beatings, it becomes an obstacle in the judicial process when the investigator must determine to whom the act will be held accountable, whether to all parties involved or only representatives of all the mass suspects, whereas in fact there are suspects who have met the criteria of both the act and the fault have met the elements to be convicted but not acted on by the authorities. Although in criminal law we recognize the offense of inclusion,

Based on the description on the background of the problem above, then the problem formulation can be formed as follows: What is the form of criminal responsibility for the perpetrators of the beatings committed by more than one perpetrator? What are the obstacles in the criminal justice process against the perpetrators of the beatings and their solutions?

\section{Research methods}

In the research carried out, writing uses the Sociological Juridical approach, which is research that uses the method of approach to the problem by looking at the norms or laws that apply as positive provisions, the following theories are relevant to this paper by linking their implementation to the facts contained in the field. The research specifications used are descriptive analysis research. The data used for this study are primary and secondary data. To obtain data in this study, data collection methods such as document collection, interviews, and literature study were used. The data that has been obtained is then analyzed by qualitative analysis, namely data analysis by not using numbers, but data obtained through research.

\section{Results and Discussion}

\subsection{Form of Criminal Liability against Perpetrators of Robbery Acts That Are Conducted More Than One Perpetrator}

\footnotetext{
${ }^{3}$ Muladi and Barda Nawawi, Teori-teori dan Kebijakan Pidana, Alumni, Bandung, 1998, p. 148

${ }^{4}$ Leden Marpaung, Proses Penanganan Perkara Pidana, Jakarta, Sinar Grafika, 1992, p. 21

${ }^{5}$ Dody Eko Wijayanto, Tinjauan Yuridis Tentang Tindak Pidana Pengeroyokan yang di Lakukan Oleh Anak di Bawah Umur Menurut Undang-Undang Nomor 23 Tahun 2002 Tentang Perlindungan Anak dan Undang-Undang Nomor 3 Tahun 1997 Tentang Peradilan Anak, Jurnal Hukum, FH Lamongan Islamic University, 2010 , Vol 2 p.37
} 
The results of research conducted by the author in the Blora State Court on case studies regarding Article 170 paragraph (2) of the Criminal Code concerning criminal offenses with a joint force committing violence against people who cause injuries (beatings), a manifestation of the system of criminal justice proceedings from the trial flow on the decision Number 94 / Pid.B / 2019 / PN Bla. As for the position of the case, the indictment of the Public Prosecutor, and the verdict, which the compiler will describe as follows as a form of criminal liability against the perpetrators of the beating crimes that are processed in the criminal justice process:

\subsubsection{Case Position}

- That the defendant KUSNADI Als CURUT Bin JARIYO together with the defendant AHMDAD KHOIRUL WAFA Bin AHMAD SALIM and the defendant SUPRIYADI Als SUPIK Bin SUNTORO on Sunday April 212019 at approximately 00.00 WIB or at least at the time which is still included in April 2019 or at least in 2019 located on the village road Turut Tanah Adirejo Village Tunjungan District Blora Regency and on the edge of the front road where the car wash is Dukuh Maguan Tamanrejo Village Tunjungan District Blora Regency or at least it is still included in the jurisdiction of Blora State Court, authorized to examine and try this case, openly and jointly using violence against people or goods, if intentionally destroys an item or if the violence used causes injury, the acts are carried out by the defendants in the following manner: ${ }^{6}$

Starting on Sunday, April 21, 2019, at around 23.45 West Indonesian Time witnesses Victim ILWAN YULIO Als KOJRENG Bin NARTO left home together with Br. SEPTIAN NICE for traveling in a Honda Brio when you arrive on the village road Adirejo turns toward the Hamak hamlet, when going into the road it is very crowded because there are people who have intentions so that the witness backs up and stops at the bridge. Next suddenly witness Ms. UCl (singer who performed in a public interest) came by riding a motorcycle and asked witnesses to help them to take to the stage to take the sandals that were left behind. Next the witness with Ms. UCl rides a brown Honda Scopy motorbike to a place that has a special intention to be intercepted by an unknown person while taking a motorcycle key while shouting "iki lho OJRENG" then the young comrades immediately arrive and immediately gang up and do beatings and the witnesses kicked themselves repeatedly and as a result of the kick that hit his back the victim fell on the asphalt road and when he fell was still kicked and trampled by the perpetrators, then there were witnesses who helped and invited him aside from the scene and headed to the car, but at that time the young men continued to chase and someone hit the back of the head. Then the witness together with witness Br. SEPTIAN NICE drove the car to the east and the driver was Br. SEPTIAN NICE and on arrival in front of the car wash stopped and suddenly a car turned around and stopped near the car and the driver got off and it turns out he was a witness Br. NANDI PLONCO and approached to the witness's place and asked to get out of the car and when it came down suddenly came a motorcycle and stopped behind the car and immediately gang up and beat a group of witnesses until they fell on the ground and when he fell the witness was kicked, were trampled and someone got out of his car NANDI PLONCO and immediately took the beating of the witness and the incident occurred approximately 10 (ten) minutes, then Br. NANDI PLONCO requested that the witness / victim immediately leave the place and finally go

\footnotetext{
${ }^{6}$ Decision Number 94 / Pid.B / 2019 / PN Bla
} 
together with Ms. UCl by riding a motorcycle to the east. As a result of this incident the witness / victim suffered / suffered bruises / swelling on the upper lip, cuts and bleeding on the right cheek, wounds applied or bruised on the temples above the right eye, bruises on the left eye, bruises on the back of the tail, wounds torn and bleeding in the right ankle inside, abrasions on the right and left elbows, blisters on the right wrist and for these injuries received care and treatment at the Tunjungan Health Center and reported the incident to the Tunjungan District Police Station. ${ }^{7}$

Whereas due to the actions of the defendant KUSNADI Als CURUT Bin JARIYO together with the defendant AHMDAD KHOIRUL WAFA Bin AHMAD SALIM and the defendant SUPRIYADI Als SUPIK Bin SUNTORO caused witnesses to the victim ILWAN YULIO Als OJRENG Bin NARTO Visum et Repertum Number: 330/232 / IV / 2019 dated April 25, 2019 made and signed by a doctor at UPT Puskesmas Tunjungan.

\subsubsection{Indictment of Public Prosecutors}

Primair: indicted for violating Article 170 paragraph (2) of the 1st Penal Code. In the subsidair indictment the public prosecutor stated the defendant openly and with force together using violence against people or property, which resulted in injuries; Subsidair: charged with violating Article 170 paragraph (1) of the Criminal Code. Stating the accused openly with joint force using violence against people or property, threatened with a maximum prison sentence of five years and six months.

\subsubsection{Amar Decision}

Considering, that the Defendants have been indicted by the Public Prosecutor on a subsidiary charge, the Panel of Judges first considered the primary indictment as provided for in Article 170 paragraph (2) 1 of the Criminal Code Act, the elements of which are as follows:

- Whoever;

- Publicly jointly committed violence against people or goods;

- Which results in damage to the goods or cause injury.

Observing, Article 170 paragraph (2) 1 of the Criminal Law Act and Act No. 8 of 1981 concerning Criminal Procedure Law and other relevant laws and regulations Defendant 1 KUSNADI, Defendant II AHMAD KHOIRUL WAFA, and Defendant III SUPRIYADI was legally and convincingly proven guilty of committing a crime in public together with committing violence against a person resulting in injury as in Primair's indictment, Dropping the criminal charge on the Defendants and therefore imprisonment each for 7 (seven) months.

As in the case of combined criminal justice is a combination of relative theory. According to the combined theory, the criminal goal is always to repay the wrongdoing of criminals also intended to protect the public by realizing order with the provisions of the severity of the criminal must not exceed the limits of fair retribution. ${ }^{8}$

\subsection{Obstacles in Criminal Justice Process against Perpetrators and the Solution}

The beating crime is a crime that can be classified in the category of collective violence, because in committing acts of violence in groups. Usually collective crimes have several

\footnotetext{
${ }^{7}$ Decision Number 94 / Pid.B / 2019 / PN Bla

${ }^{8}$ Samosir, Djisman, Fungsi Pidana Penjara Dalam Sistem Pemidanaan di Indonesia, Bina Cipta, Bandung, 1992, p. 41
} 
characteristics such as, transferring individual identity and responsibility into group identity and responsibility, the relationship between individual and mass becomes very immersonal, suggestive and infectious. ${ }^{9}$

From the judge's point of view as a result of the author's interview with Yunita, SH, one of the judges at the Blora State Court explained the obstacles faced in the process of beatings during this time raised complex obstacles. These obstacles include: ${ }^{10}$

- The investigation process in bringing witnesses

The obstacles faced by investigators in the framework of making the Minutes of Investigation on the case are the lack of witnesses and perpetrators who do not want to admit their actions, as well as the perpetrators' information that is always changing and the beatings are carried out in a crowd, the perpetrators tend to protect one another, because if there is who claims to have a legal and detrimental effect on himself, so that he is unwilling to be a witness because being a witness will show that he is also a criminal offender. But in this case the key to the strong information around the case is the key to the success of the criminal investigation. This is to avoid procedural mistakes in exposing more than one person with a beating crime.

- Prosecution process that takes time

In the Criminal Procedure Code in Article 141 that the public prosecutor can merge cases with one indictment. But the possibility of incorporation is limited by the conditions of the article. the claimant in this case can immediately split the file into several pieces. What needs to be asked from the investigator is a duplicate of the results of the examination, because it is very useless if only to be broken down into a number of case files it must go back and forth from the public prosecutor to the investigator, and is not in accordance with the principle of quick justice.

In a criminal act carried out more than one person, so it is possible to be combined if the perpetrators are proven to have committed the same act. On the authority of the public prosecutor to do the separation of the perpetrators from one another can be done as stated in article 142 of the Criminal Procedure Code. But the public prosecutor did not do even though in reality the series of actions was carried out together. Which is important to mention that there are other defendants in the same case who are important to know by the public.

- Article 170 of the Criminal Code still has theoretical confusion

Theoretically, Article 170 of the Indonesian Criminal Code contains constraints and smells of controversy because the subject "whoever" designates the perpetrators of one person, while the term "with joint power" indicates a group of people. This offense, according to his explanation, was not aimed at groups or masses who did not regularly commit criminal acts, the threat was only directed at people within the group who were truly proven and by force together to commit violence.

Problems in Indonesian Criminal Law, especially the problem of inclusion in the Criminal Code where the substance of the unclear provisions will make it difficult for judges as law enforcers, because in making judges' decisions, they must be guided by the law. In applying the provisions of the Act (criminal) in a concrete case, the judge is allowed to make

\footnotetext{
${ }^{9}$ Adhi Wibowo, Perlindungan Hukum Korban Amuk Massa, Thafa Media, Yogyakarta, 2013

${ }^{10}$ Results of an Interview with Yunita, SH, Judge of the Blora District Court, on November 28, 2019
} 
interpretations that are commonly used in criminal law. Judges in general can also use the opinion of legal experts (doctrine) as a guide in deciding a case. But not infrequently the opinions of scholars on a matter are not the same, sometimes even conflicting. Therefore the judge must choose according to his conscience, which opinion is most appropriate to be applied in the case he is facing. Article 170 of the Criminal Code.

\section{Closing}

\subsection{Conclusions}

- Case regarding Article 170 paragraph (2) of the Criminal Code concerning criminal offenses with joint personnel committing violence against persons resulting in injuries (beatings), a form of the system of criminal justice process of the trial flow in the decision No. 94 / Pid.B / 2019 / PN Blah as a form of criminal liability against the perpetrators of criminal beatings that are processed in the criminal justice process;

- These obstacles include the investigation process in presenting witnesses, the timeconsuming prosecution process, and article 170 of the Criminal Code which still has a theoretical confusion in the judge's view as the role of law enforcement authorities who are authorized to decide cases.

\subsection{Suggestions}

- Public prosecutors and judges in prosecuting and adjudicating a case must prioritize legal certainty and must be more careful and careful in considering matters revealed in court for the realization of justice based on the Almighty God as stated in each of its decisions;

- Legal provisions and the application of criminal sanctions against offenders who jointly commit violence resulting in serious injury to the decision Number 94 / Pid.B / 2019 / PN $\mathrm{Bla}$, should be re-considered, because it is still far from the goal of punishment which is to provide a deterrent effect on criminal offender.

\section{References}

\section{Book}

[1] Leden Marpaung, 1992, Proses Penanganan Perkara Pidana, Jakarta, Sinar Grafika.

[2] Muladi and Barda Nawawi, 1998, Teori-teori dan Kebijakan Pidana, Alumni, Bandung.

[3] Samosir, Djisman, 1992, Fungsi Pidana Penjara Dalam Sistem Pemidanaan di Indonesia, Bina Cipta, Bandung.

\section{Journal}

[1] Dody Eko Wijayanto, Tinjauan Yuridis Tentang Tindak Pidana Pengeroyokan yang di Lakukan Oleh Anak di Bawah Umur Menurut Undang-Undang Nomor 23 Tahun 2002 Tentang Perlindungan Anak dan Undang-Undang Nomor 3 Tahun 1997 Tentang Peradilan Anak, Jurnal Hukum, FH Lamongan Islamic University, 2010, Vol 2

\section{Documents}

[1] Decision Number 94 / Pid.B / 2019 / PN Bla 